\title{
ЕТАПИ СТАНОВЛЕННЯ ТА РОЗВИТКУ НАУКОВИХ ПОГЛЯДІВ СТОСОВНО ФЕНОМЕНУ «КОРПОРАТИВНА КУЛЬТУРА»
}

\author{
Авдєєва А. В., Цільмак О. М.
}

\begin{abstract}
У статmі проаналізовано історичні аспекти виникнення та розвитку наукових поглядів щодо феномену корпоративної культури. Виокремлено основні етапи становлення корпоративної культури. Висвітлено стан дослідження феномену корпоративної культури в Національній поліції України. 3 урахуванням вітчизняного і зарубіжного досвіду зроблено висновки щодо необхідності дослідження юридико-психологічних аспектів корпоративної культури поліцейських.
\end{abstract}

Ключові слова: культура, корпоративна культура поліцейських, етапи становлення, Національна поліція, розвиток організації.

В научной статье проанализированы исторические аспекты возникновения и развития научных взглядов относительно феномена корпоративной культуры. Выделены основные этапы становления корпоративной культуры. Освещено состояние исследования феномена корпоративной культуры в Национальной полиции Украины. С учетом отечественного и зарубежного опыта сделаны выводы касательно необходимости исследования юридико-психологических аспектов корпоративной культуры полицейских.

Ключевые слова: культура, корпоративная культура полицейских, этапы становления, Национальная полиция, развитие организации.

The scientific article analyzes the historical aspects of the emergence and development of scientific views on the phenomenon of corporate culture. There are three main stages of corporate culture formation (Phase I - the emergence of scientific views on corporate culture and its components (XIX century - 70-ies. XX century). Stage II - intensification of research on the phenomenon of corporate (organizational) culture (80ies. years of XX century - beginning of XXI century.); III stage national research of corporate culture (beginning of XXI century - untill now)). Each of these stages has scientific achievements and inventions are certain, in particular in labours defined: concept, signs, component elements, functions, approaches to determining the level of formation, ways of strengthening of corporate culture and others.

It is emphasized that the modern period of development of our country is characterized by changes and large-scale transformations that are occurring in the bodies and units of the National Police of Ukraine. The state of research of the corporate culture phenomenon in the National Police of Ukraine is also covered.

It is specified that the corporate culture of police officers should be considered as a set of normative moral and ethical principles, norms, rules and standards of police behavior, which determine their overall level of life-culture and provide effective solution to the professional and official tasks of law enforcement and law enforcement activities. Therefore, the development and justification of scientific and practical recommendations on the basic provisions of the corporate culture of police officers, based on the study of the legal and psychological aspects of corporate culture in the National Police, is quite relevant. As this

Авдєєва А. В., Цільмак О. М., 2019 will help to generate positive public opinion on the professional activities of police officers, improve the image of the service in the ranks of the National Police, attract new staff and more.

Key words: culture, corporate culture of police officers, stages of formation, National police, organization development.

Постановка проблеми та її актуальність. Повноцінне функціонування будь-якого колективу неможливе без визначення основних правил взаємодії між суб'єктами цих відносин. Спілкування в площині «керівник - підлеглий», «працівник - працівник» або «працівник - заявник» вимагає чіткої регламентації, дотримання норм і правил як самої організації, так і суспільства в цілому.

У сучасних умовах розвитку суспільства до державних службовців всіх ланок управління прикута дуже значна увага, тому надзвичайно важливою $€$ така сфера суспільного життя, як культура, особливо корпоративна й організаційна, яка $\epsilon$ свого роду корінням (фундаментом) організації, від міцності якого залежить стійкість та рівень сприйняття останньої спільнотою.

Сьогодні відбуваються трансформації й в уявленнях образу сучасного поліцейського, тому розроблення та обґрунтування науково-практичних рекомендацій щодо основних положень корпоративної культури поліцейських на основі дослідження юридико-психологічних аспектів корпоративної культури в Національній поліції $є$ доволі актуальним.

Аналіз останніх досліджень i публікацій. Для опису культури організації дослідники користуються різноманітними близькими за сенсом термінами, такими як «управлінська культура», «виробнича культура», «культура трудових відносин», «організаційна культура», «ділова культура», «підприємницька культура», «внутрішня культура компанії», «корпоративна культура», «організаційний клімат» тощо. Дуже важливим $€$ розуміння того, чи $є$ ці визначення тотожними, в чому полягає різниця між ними, оскільки велика кількість різноманітних визначень корпоративної і організаційної культури, які в багатьох випадках суперечать одне одному, викликає багато труднощів для пізнання і застосування на практиці. Для логічної послідовності і цілісності даного дослідження необхідно визначити поняття «організація» $\mathbf{i}$ «корпорація».

Етимологія поняття «організація» пов'язана с латинським корінням (“organizo" - «спільно, стрункий вид, влаштовую») і використовується в декількох значеннях, одне з яких - об'єднання людей, суспільних груп, держав на базі спільності інтересів, мети, програми дій тощо.

У науці термін «організаційна культура» був запропонований американським соціологом Т. Парсонсом у 1956 р. Він розглядав організацію як систему, яка являє собою стійкий комплекс повторюваних і взаємопов'язаних соціальних дій. Система в цілому і їі елементи виконують функції, зумовлені цільовим аспек- 
том системи та її структурою. Т. Парсонс виділяв такі чотири підсистеми в загальній системі соціальної дії: біологічний організм, систему особистості, соціальну систему, систему культури. Елементи системи соціальної дії утворюють ієрархію, в якій підсистема культури займає домінантне положення, оскільки цінності и соціальні норми суспільства керують діями його членів і тим самим забезпечують здатність спільного соціального життя. Отже, підсистема культури виконує нормативну функцію. Саме цю підсистему ми і будемо аналізувати в процесі нашого дослідження.

Економічні, політичні і соціальні зміни життя обов'язково проєктуються на організаційне середовище, впливаючи на нього прямо чи опосередковано. Зовнішні фактори впливають на всі ресурси організації - матеріально-технічні, людські, інформаційні, фінансові. Завдяки цьому процесу відбуваються організаційні зміни, які впливають на сприйняття організації оточуючими.

Що стосується корпорації, то вона являє собою організацію, в чомусь близьку, однак і відмінну від інших людських організацій, таких як громади, асоціації, союзи, інститути тощо. Особливість корпорації полягає в тому, що вона об'єднує людей за професійними ознаками, но також включає й інші зв'язки, які дозволяють індивіду відчути стабільність та ідентичність у своїй соціальній групі.

Існує різноманіття тлумачень терміна «корпорація» залежно від наукової галузі, яка розглядає цей термін.

У правовій літературі корпорація розглядається як форма організації підприємницької діяльності, яка передбачає договірне об'єднання, створене на основі поєднання виробничих, наукових і комерційних інтересів підприємств, що об'єдналися, з делегуванням ними окремих повноважень централізованого регулювання діяльності кожного з учасників органам управління корпорації.

У рамках загальносоціологічного підходу існує два варіанти трактування корпорації: по-перше, це група осіб, які об'єднані за професійними, комерційними, становими інтересами; по-друге, це елемент соціальної структури.

На думку І. Храбрової, найбільш осмислене визначення корпорації надане в американській економіко-правовій системі: «Корпорація - це організація, яка ставить перед собою певні цілі, націлена на суспільне благо, володіє певними правами, зареєстрована відповідно до законодавства, діє на постійній основі і несе обмежену відповідальність»[1].

Отже, аналізуючи визначення корпорації, ми виявляємо деякі загальні риси, такі як форма організації, наявність структури и наявність спільних інтересів, управлінські функції і володіння юридичними правами. У такому розумінні корпорація виступає як елемент соціальної структури, певна відособлена цілісна самодостатня група, суб'єкт діяльності, який володіє юридичними правами, власністю, тобто як система взаємодій і зв'язків.

3 огляду на це корпоративність можна інтерпретувати як спосіб дій певної групи, об'єднаної спільними інтересами, яка має власний статус. Корпоративність це принцип, який розкриває взаємовідносини особистості і групи, особистості і суспільства, групи і суспільства.

Корпоративну організацію можна визначити як особливу систему зв'язків між людьми в процесі здійснення ними спільної діяльності. Корпоративні організа- ції за формою і змістом досить різноманітні, але вони схожі за своєю суттю, адже всі вони об'єднують людей за певними якостями та інтересами для реалізації конкретних цілей.

Отже, можна вважати, що терміни «корпоративна культура» $\mathbf{i}$ «організаційна культура» $\epsilon$ схожими за своїм значенням і змістом, часто використовуються як синоніми. Однакдляцьогодослідження доцільнимєвживання терміна «корпоративна культура», оскільки це поняття найбільш конкретно відображає структуру і зміст діяльності Національної поліції України в сучасних умовах.

Корпоративна культурау такомувигляді, як вона існує сьогодні, склалася відносно нещодавно. Це не означає, що іï не існувало зовсім. Вона розвивалась у вигляді окремих думок і сприймалась як щось сформоване.

Метою статті $\epsilon$ аналіз наукових праць вітчизняних і зарубіжних вчених з різних галузей, виокремлення етапів становлення та розвитку наукових поглядів стосовно феномену корпоративної культури.

Виклад основного матеріалу. Проаналізувавши наукові погляди щодо ґенези феномену корпоративної культури, ми вважаємо, що слід виділити певні етапи ії становлення.

І етап - зародження наукових поглядів щодо корпоративної культури та її складників (XIX ст. - 70-ті рp. XX ст.). Представниками цього етапу були Гельмут Карл Бернхард фон Мольтке, Ф. Тейлор, А. Файоль, М. Шериф, Е. Джакус та ін.

Першим представником цього етапу був Німецький фельдмаршал, військовий теоретик Гельмут Карл Бернхард фон Мольтке, який використовував поняття «корпоративна культура» для характеристики взаємин в офіцерському середовищі.

З 1895 року Фредерік Тейлор почав свої дослідження з наукової організації праці, відомі у всьому світі.

У 1916 році, всього через кілька років після публікації Ф. Тейлором своєї теорії організації управління, французький теоретик і практик менеджменту Анрі Файоль опублікував роботу «Загальне i промислове управління», де узагальнив напрацьовані ним схеми управління, створивши системну теорію менеджменту.

На початку XX століття одним із перших це поняття використав Музафер Шериф, турецький психолог, автор низки відомих експериментів в соціальній психології, у своїй книзі «Психологія соціальних норм» у 1936 році.

У літературі доволі часто трапляється думка, що концепція корпоративної культури бере свій початок з так званих Хоторнських експериментів, які були проведені з 1925 до 1932 рр. на фабриці «Вестерн Электрікс» в США групою дослідників, яку очолював Елтон Мейо. Тоді завдяки анонімним опитуванням працівників заводу вдалося встановити, що в колективі існують неофіційні норми поведінки, які в окремих випадках перешкоджали спробам керівництва удосконалити виробництво. Саме після Хоторнських експериментів вчені почали замислюватись про вплив взаємовідносин в колективі на продуктивність праці.

У 1952 році англієць Елліотт Джакус, якого можна вважати одним 3 основоположників організаційної культури, у своїй книзі надав визначення культури підприємства як образу мислення, способу дії, трансформованого в звичку, який поділяють усі працівники тією чи іншою мірою та який повинні сприйняти новачки, щоб адаптуватися в колективі. 
До початку 80-х років XX століття систематичного розроблення корпоративної (організаційної) культури в літературі не відмічалося, були тільки поодинокі й епізодичні спроби осягнути це явище. Це питання не мало відгуку серед науковців, дослідників та осіб зі сфери управління. Американські дослідники почали займатися цим поняттям в 1970-1980-х роках, проте важливо зазначити, що термін «корпоративна культура» ще не виник в той час.

Представниками цього етапу були професори Гарвардської школи бізнесу Ренато Таджурі і Джордж Літвін, які вивчали організаційну (корпоративну) культуру в рамках концепції організаційного клімату. Свої напрацювання вони виклали у виданій 1968 року книзі «Організаційний клімат: дослідження концепції». У 70-ті роки в США були опубліковані праці Х. Транса, в яких приділялася увага різноманітним традиціям, обрядам і ритуалам, прийнятим в організаціях.

Думка про те, що організації мають свої культури, висловлювалася багатьма дослідниками, більшість з яких вважала, що основи теорії корпоративної культури були закладені в 1973 році американським соціологом Кліффордом Гіртцем в книзі “The Interpretation of Cultures”.

У вітчизняній науці на даному етапі розвитку окремі питання корпоративної культури були описані видатним українським педагогом і письменником, розробником теорії і методики виховання в колективі А. Макаренком. Про цінності і норми поведінки як компоненти культури зазначав у своїх творах В. Сухомлинський.

II етап - активізація досліджень феномену корпоративної (організаційної) культури (80-ті рр. XX ст. - початок XXI ст). Представниками цього етапу були А. Кеннеді, П. Друкер, Е. Шейн, К. Камерон і Р. Куінн, С.П. Роббінс, Р. Уотерман та ін.

Новий етап розвитку корпоративної культури розпочався у 80-х роках XX століття після публікації праць низки зарубіжних дослідників. У 1982 році американські науковці звернули увагу на раціональні управлінські теорії, на яких базуються універсальні методи взаємин у колективі, і відзначили, що ті перестали себе виправдовувати. Виявилося, що однакові управлінські впливи в різних організаційних середовищах викликають різні, а іноді і протилежні поведінкові реакції, а сам механізм управління багато в чому визначається традиціями та культурними особливостями.

Ці дослідження дуже вплинули на розвиток корпоративної культури. Вчені чітко сформулювали ідею про те, що особа, яка впливає на стан справ в організації, повинна займатися не тільки економічними питаннями, але й керувати ціннісними установками організації, тобто створювати сенс роботи в цій компанії.

Корпоративна культура описувалася у різних галузях науки. Так, в галузі економіки представниками були А. Кеннеді («Корпоративна культура», 1982), Д. Грейвз («Корпоративна культура: діагноз і зміни», 1986), А. Вілкінс («Розвивальний корпоративний характер», 1989), Дж. Тернер («Створюючи корпоративну культуру: від розбіжностей до гармонії», 1992), К. Берквіст («Постмодерні організації», 1993) та ін.

Дослідження Т. Діла і А. Кеннеді, Т. Пітерса і Р. Уотермена викликали чималий інтерес до розробки поняття «корпоративна культура», оскільки цим вченим вдалося продемонструвати переваги компаній, які мають сильну та виважену культуру.
У галузі соціології та у сфері організаційного управління нові або трансформовані погляди пропонують Пітер Друкер, Р. Блейк, К. Шольц, М. Мексон. Першою важливою теоретичною працею з розгляду даної проблеми вважають книгу американського психолога Е. Шейна «Організаційна культура і лідерство» (1985). Свій внесок на даному етапі зробив і німецький психолог Рольф Рютінгер, який детально розробив соціально-психологічні моделі корпоративної культури. Окремих питань корпоративної культури в своїх розробках торкався психолог Девід Мацумото.

Одними з найвідоміших дослідників питань організаційної культури є американські менеджери, визнані світом фахівці у сфері вирішення соціальних питань в організації К. Камерон і Р. Куінн. Запропонована ними типологія організаційної культури вважається універсальною, тобто їі можна адаптувати під будь-яку організацію чи підприємство. Базується вона на чотирьох групах критеріїв, які визначають стрижневі цінності організації. До першої групи віднесено гнучкість та дискретність, до другої - стабільність і контроль, до третьої групи - внутрішній фактор та інтеграцію, до четвертої належать зовнішній фактор та диференціація.

III етап - вітчизняні дослідження корпоративної культури (початок XXI ст. - досі). Представниками цього етапу були В. Співак, Ю. Палеха, Г. Хаєт, Л. Карамушка, Н. Завацька, К. Гнєзділова, Н. Наконечна та ін.

Так, В. Співак стверджував, що дуже часто в основі зростання або втрати довіри до організації $є$ обставини, які прямо чи опосередковано належать до ії корпоративної культури. Стиль керівництва, психологічний клімат в колективі, сформований імідж - все це впливає на результати діяльності будь-якого колективу. Керівник повинен вміти передбачати наслідки своїх рішень, в тому числі і в культурологічному аспекті. У своїй книзі він дає відповіді на ключові запитання, які виникають в процесі побудови єдиної корпоративної структури організації, внутрішньоорганізаційних взаємовідносин та репутації.

Ще один представник соціології А. Пригожин вважає, що вміло визначивши функції, мотивацію, розвиток стосунків між працівниками, узгодження інтересів, залучивши працівників до вироблення загальних цілей, можна розвинути організаційну культуру до рівня корпоративної, коли інтереси і дії працівників максимально зосередяться на меті організації в цілому.

Існують також філософські погляди на феномен корпоративної культури. Так, А. Заньковський розглядав корпоративну культуру як набір філософських та ідеологічних уявлень, цінностей, переконань, сподівань, атитюдів і норм, які пов'язують організацію в єдине ціле та поділяються усіма її представниками. Ю. Палеха вважав, що системоутворюючим фактором організаційної культури $є$ стан середовища, що формується та розвивається особистостями та колективами. І.С. Семененко акцентував увагу на тому, що майже відсутні фахівці з питань формування і розвитку корпоративної культури, не здійснюється їх підготовка, відсутні механізми розповсюдження передового досвіду у цій сфері.

У галузі менеджменту на цьому етапі проводиться велика кількість фундаментальних досліджень як корпоративної культури, так і окремих їі складників. Так, О. Виханький і А. Наумов вважали, що організаційна культура складається зі стійких норм, уявлень, принципів і вірувань відносно того, як ця організація має и може 
реагувати на зовнішні впливи, як треба поводити себе в організації, який сенс у функціонуванні організації тощо.

М. Виходець у своїй монографії висвітлив теоретичні та практичні засади культури організації. Він проаналізував такі питання, як психологічні риси співробітників, стиль і манера взаємовідносин, корпоративна культура, інтелектуальна влада менеджера, менеджерський етикет. Вчений розглянув нові підходи до конфліктних ситуацій, ключові елементи культури й антикультури, вплив хвороб і лікарських препаратів на виконання службових обов'язків.

М. Гакова у своїх дослідженнях дійшла висновку, що корпоративна культура - це інструмент в руках менеджера, за допомогою якого можливо істотно впливати на результативність поведінки персоналу підприємств готельно-ресторанного господарства. В умовах мінливого зовнішнього і внутрішнього корпоративного середовища феномен культурного потенціалу може забезпечити економічній системі досягнення більшої стійкості, інноваційної сприйнятливості, конкурентні переваги та здатність до постійного розвитку.

Особливий інтерес становлять наукові розробки в галузі психології і педагогіки. Численна кількість робіт підкреслює зацікавленість фахівців з різних сфер і галузей розвитком корпоративної культури.

Широке коло питань розкривається в начальному посібнику за загальною редакцією Григорія Львовича Хаєта [2], де визначено, що корпоративна культура могутній і потужній інструмент управління персоналом. Розвиток корпоративної культури пояснюється взаємозв'язком з видом менеджменту, середовищем, періодами часу, технологією і особистістю того, хто працює. Посібник містить багато конкретних методик - моніторингу корпоративної культури, її кваліметричної оцінки, планування розвитку, психологічного тренінгу, навчання із залученням слухачів у процес діяльності тощо.

Вагомим внеском в розвиток феномену організаційної культури в галузі психології можна вважати монографії, посібники та статті відомого фахівця у сфері організаційної та економічної психології Л. Карамушки. Значущість організаційної культури для професійного становлення членів організацій та їх трудової адаптації підкреслювала Н. Завацька. Вона запропонувала методику визначення функцій корпоративної культури.

У галузі педагогіки серед актуальних проблем професійної підготовки майбутніх викладачів вищої школи К. Гнєзділова вважала недостатньо дослідженим питання формування їх корпоративної культури. Вчена зазначала, що розв'язання цієї проблеми можна здійснити шляхом упровадження у процес магістерської підготовки майбутніх викладачів розробленої педагогічної системи.

3 останніх робіт в галузі психології привертає до себе увагу дисертація Н. Наконечної «Психологічні умови розвитку корпоративної культури вищого навчального закладу приватної форми власності», захист якої відбувся у 2016 році. У результаті здійснення цього дослідження були теоретично обґрунтовані психологічні умови розвитку корпоративної культури вищого навчального закладу. Також була практично доведена можливість та доцільність психокорекції.

Особливий інтерес становлять наукові дослідження корпоративної культури в силових структурах А. Метелькова («Формування організаційної культури майбутніх прикордонників», 2010), О. Ходаня («Крите- рії та показники сформованості корпоративної культури майбутніх офіцерів: результати дослідження», 2010), Л. Шемчука («Критерії, показники і рівні сформованості корпоративної культури майбутніх офіцерів органів внутрішніх справ», 2014) [3], О. Цільмака («Правові та психологічні основи корпоративної міліцейської культури», 2014) [4].

Отже, третій етап ознаменувався широким розповсюдженням на території України феномену корпоративної культури. Були проведені фундаментальні дослідження в соціології та організаційно-управлінській сфері, економіці, в сфері кадрового менеджменту, філософії, організаційній психології, психології праці, педагогіці, юридичній психології. Результатами цих досліджень стали численні наукові доробки та винаходи, в яких визначалися поняття, ознаки, складники, функції, підходи до визначення рівня сформованості, а також шляхи зміцнення корпоративної культури тощо. Провідні фахівці та експерти ще більше переконуються у тому, що гнучка, виважена, спрямована на результат корпоративна культура $\epsilon$ потужною рушійною силою організації, за допомогою якої підвищується мотивація співробітників. Наслідком такого підвищення $\epsilon$ зростання рівня розвитку організації.

Висновки. Корпоративна культура впливає на усі сфери життя особи (як на професійну, так і на соціальну). На нашу думку, корпоративною культурою поліцейських слід вважати сукупність нормативно закріплених морально-етичних принципів, норм, правил і стандартів поведінки поліцейських, які визначають їх загальний рівень життєдіяльнісної культури та забезпечують ефективне вирішення професійних і службових завдань правоохоронної та правозастосовної діяльності. Отже, сьогодні постає необхідність у розробці та обґрунтуванні науково-практичних рекомендацій щодо напрямів корпоративної культури поліцейських на основі дослідження юридико-психологічних аспектів корпоративної культури в Національній поліції. Це сприятиме формуванню позитивної думки громадськості щодо професійної діяльності поліцейських, підвищенню іміджу служби в лавах Національної поліції, залученню нових кадрів тощо.

\section{Література}

1. Храброва И.А. Корпоративное управление: вопросы интеграции. Москва : ИД «Альпина», 2000. 198 с.

2. Корпоративна культура: навчальний посібник / Хаєт Г.Л., Єськов О.Л. та ін. ; за заг. ред. Г.Л. Хаєта. Київ : Центр навчальної літератури, 2003. 403 с.

3. Шемчук Л.О. Корпоративна культура як предмет наукових досліджень. Наукові записки Вінницького державного педагогічного університету імені Михайла Коцюбинського. Серія «Педагогіка і психологія». Випуск 40. 2013. С. 133-137.

4. Цільмак О.М. Правові та психологічні основи корпоративної міліцейської культури. Південноукраїнський правничий часопис. 2014. № 2. С. 150-152.

Авдєєва А. B., ад’юнкт денної форми навчання докторантури та аспірантури одеського державного університету внутрішніх справ

Цільмак О. М., доктор юридичних наук, професор, професор кафедри соціології та психології Національного університету «Одеська юридична академія» 